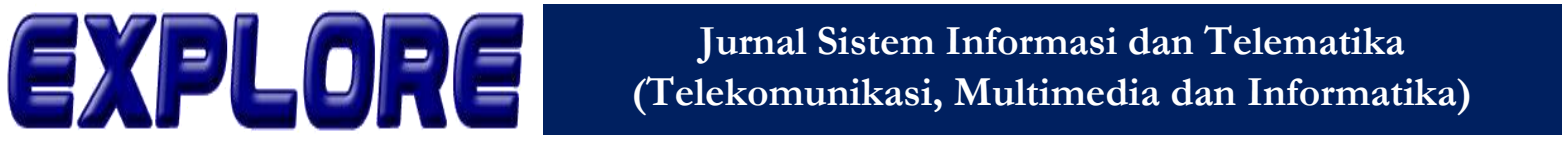

\section{Aplikasi Pemesanan Ambulan Berbasis Web}

\author{
Putri Sri Rahayu, Wuwuh Bekti Hartiningsih \\ Jurusan Sistem Informasi \\ Universitas Mercu Buana \\ Bekasi, Indonesia \\ putri.srirahayuu51@gmail,wuwuh.bekti@mercubuana.ac.id
}

\begin{abstract}
One of the transportation in an emergency situation is an ambulance provided by the Department of Health for health facilities in the community. Useful to assist the community in providing first aid and intensive care while the patient is on his way to the referral hospital. As for the complaints experienced by the public at this time is the difficulty in ordering an ambulance. While the hospital often has difficulty in finding the location of the community who made an ambulance booking. One of the innovations in hospital health services by utilizing the development of information technology is by making a "Web-Based Ambulance Application". The aim is to make it easier for patients / customers to be referred to the nearest hospital that has the appropriate facilities for the need for effective medical treatment to get emergency response ambulance services quickly and accurately through addresses for patient pickup. The benefits obtained from this application are easier for patients to access the nearest hospital location, and increase patient / community satisfaction with health services. The method used in developing this application is the waterfall model and through analyzing the needs of PIECES (Performance, Information, Economics, Control, Efficiency, Service) in finding the main problem.
\end{abstract}

Keywords : Health services, IGD, Hospitals, Web, waterfall model, PIECES

\begin{abstract}
Abstrak- Salah satu transportasi dalam keadaan gawat darurat adalah ambulan yang disediakan oleh Dinas Kesehatan untuk fasilitas kesehatan di masyarakat. Berguna untuk membantu masyarakat dalam melakukan pemberian pertolongan pertama dan perawatan intensif saat pasien sedang dalam perjalanan menuju rumah sakit rujukan. Adapun keluhan yang dialami masyarakat saat ini adalah kesulitan dalam melakukan pemesanan ambulan. Sedangkan di pihak rumah sakit sering mengalami kesulitan dalam menemukan lokasi masyarakat yang melakukan pemesanan ambulan. Salah satu inovasi di pelayanan kesehatan rumah sakit dengan memanfaatkan perkembangan teknologi informasi yaitu dengan membuat "Aplikasi Pemesanan Ambulan (Go Ambulanc) Berbasis Web". Adapun tujuan nya adalah memudahkan pasien/pelanggan dapat dirujuk ke rumah sakit yang terdekat yang memiliki fasilitas yang sesuai dengan keperluan untuk penanganan medis secara efektif guna mendapatkan layanan ambulan tanggap darurat dengan cepat dan akurat melalui alamat untuk penjemputan pasien. Manfaat yang diperoleh dari aplikasi ini adalah mempermudah pasien dalam mengakses lokasi rumah sakit yang terdekat, dan meningkatkan kepuasan pasien / masyarakat terhadap pelayanan kesehatan. Metode yang digunakan dalam mengembangkan aplikasi ini adalah model waterfall dan melalui analisa kebutuhan PIECES (Performance, Information, Economics, Control, Efficiency, Service) dalam menemukan pokok masalah.
\end{abstract}

\section{Kata Kunci : Pelayanan kesehatan , IGD, Rumah Sakit, Web, model waterfall, PIECES}

\section{Pendahuluan}

Kesehatan merupakan hak asasi manusia dan salah satu unsur kesejahteraan yang harus diwujudkan sesuai dengan cita-cita Bangsa Indonesia sebagaimana dimaksud dalam Pancasila dan Undang-Undang Dasar Negara Republik Indonesia Tahun 1945. Adapun cita cita pembangunan kesehatan sudah tertuang dalam Undang Undang Republik Indonesia No.36 Tahun 2009 Pasal 2, berbunyi pembangunan kesehatan diselenggarakan dengan berasakan perikemanusiaan, keseimbangan, manfaat, perlindungan, penghormatan terhadap hak dan kewajiban, keadilan, gender dan nondiskriminatif dan norma norma agama. Sedangan tujuan dari pembangunan kesehatan tertuang dalam Undang Undang Republik Indonesia No.36 Tahun 2009 Pasal 3, berbunyi pembangunan kesehatan bertujuan untuk meningkatkan kesadaran, kemauan, dan kemampuan hidup sehat bagi setiap orang agar terwujud derajat kesehatan masyarakat yang setinggi- tingginya, sebagai investasi bagi pembangunan sumber daya manusia yang produktif secara sosial dan secara ekonomis.[1]

Salah satu upaya pemerintah untuk merealisasikan pembangunan kesehatan sesuai dengan amanat Undang Undang Republik Indonesia No.36 Tahun 2009, maka negara membangun Fasilitas Kesehatan seperti puskesmas, rumah sakit ataupun klinik. Menurut Undang Undang Republik Indonesia No.44 Tahun 2009 Pasal 1 tentang rumah sakit, bahwa rumah sakit adalah institusi pelayanan kesehatan yang menyelenggarakan pelayanan 
kesehatan perorangan secara paripurna yang menyediakan pelayanan rawat inap, rawat jalan dan gawat darurat. Gawat darurat adalah keadaan klinis pasien yang membutuhan tindakan medis segera guna penyelamatan nyawa dan pencegahan kecacatan lebih lanjut. Adapun penyelenggaraan rumah sakit sudah tertuang dalam Undang Undang Republik Indonesia No.44 Tahun 2009 Pasal 2, berbunyi rumah sakit diselenggarakan berasaskan Pancasila dan didasarkan kepada nilai kemanusiaan, etika dan profesionalitas, manfaat, keadilan, persamaan hak dan anti diskriminasi, pemerataan, perlindungan dan keselamatan pasien serta mempunyai fungsi sosial. Tujuan dari penyelenggaraan rumah sakit ialah mempermudah akses masyarakat untuk mendapatkan pelayanan kesehatan, memberikan perlindungan terhadap keselamatan pasien, masyarakat, lingkungan rumah sakit dan sumber daya manusia di rumah sakit, meningkatkan mutu dan mempertahankan standar pelayanan rumah sakit, serta memberikan kepastian hukum kepada pasien, masyarakat, sumber daya manusia rumah sakit, dan rumah sakit. [2]

Peraturan Menteri Kesehatan No.71 Tahun 2013 Pasal 29 pelayanan ambulan adalah pelayanan transportasi pasien rujukan dengan kondisi darurat antar Fasilitas Kesehatan disertai dengan Upaya atau kegiatan menjaga kestabilan kondisi pasien untuk kepentingan keselamatan pasien. Ambulan gawat darurat dapat menangani pasien, memberikan pertolongan pertama dan melakukan perawatan intensif selama dalam perjalanan menuju rumah sakit tujuan. [3]

Berbagai permasalahan tentang Pelayanan Kesehatan di Indonesia cukup banyak. Salah satunya adalah akses pelayanan dalam kondisi gawat darurat yang membutuhkan pelayanan ambulan. Dimana masyarakat sulit untuk mendapatkan informasi yang jelas tentang ketersediaan jumlah ambulan di rumah sakit. Sedangkan permasalahan dari pihak rumah sakit adalah petugas rumah sakit mengalami kesulitan dalam mengakses lokasi masyarakat yang melakukan pemesanan ambulan dan keterbatasan petugas rumah sakit dalam mengelola jumlah mobil ambulan sehingga menimbulkan ketersediaan mobil ambulan sulit diperkirakan.

Berdasarkan latar belakang diatas, maka penulis mengajukan pembuatan suatu sistem yang berjudul “Aplikasi Pemesanan Ambulan Berbasis Web" tujuannya adalah untuk meningkatkan kualitas pelayanan kesehatan terutama saat melakukan pemesanan ambulan dan memastikan masyarakat sampai ke rumah sakit dengan tepat waktu, Pemesanan juga dapat diakses dengan mudah oleh setiap masyarakat dan mempermudah pemesan dalam melakukan pembayaran tanpa harus antri diloket pembayaran.[4]

Untuk memperjelas proses pembuatan aplikasi, penelitian ini akan dibatasi dengan penelitian yang dilakukan meliputi hanya pemesan yang tidak bisa mengakses fasilitas medical check-up di Rumah Sakit khusus nya wilayah Bekasi, hanya membatasi user yang digunakan yaitu pelanggan tidak bisa menambahkan atau mengedit data informasi Rumah Sakit, hanya membahas tentang Aplikasi Pemesanan Ambulan di Rumah Sakit khusus nya wilayah Bekasi, dan Pengembangan aplikasi dilakukan dengan web application menggunakan bahasa PHP dan database MySQ.[5]

\section{Metodologi}

\section{a. Metode Metode Pengumpulan Data :}

1. Observasi

Peneliti melakukan pengamatan secara langsung di Rumah Sakit Kartika Husada dan Rumah Sakit Bella untuk memperoleh data yang diperlukan. Hasil dari pengamatan masih belum menggunakan web atau aplikasi. Jadi untuk melakukan pemesanan, masyarakat terlebih dahulu harus menghubungi melalui telepon atau datang langsung ke rumah sakit.

\section{Kuesioner}

Pada tahapan ini penulis membagikan kuesioner kepada masyarakat, guna untuk menilai aplikasi yang telah dibuat, apakah sudah efiesin atau belum dan dapat meningkatkan pelayanan di rumah sakit atau tidak.

\section{Studi Pustaka}

Peneliti mengumpulkan data yang dibutuhkan seperti sumber buku, artikel, dan jurnal dan karya ilmiah lainnya yang didapatkan di internet dan literatur lainnya yang berhubungan dengan aplikasi pemesanan ambulan berbasis web.

\section{Metode Penelitian :}

Dalam pengembangan sistem penulis menggunakan Model Waterfall untuk perancangan sistem informasi, berikut adalah penjelasannya :

\section{Analisa Kebutuhan}

Pada tahap ini yang penulis butuhkan adalah dokumen awal seperti proses pendataan data mitra rumah sakit, proses pendatan admin untuk masing - masing rumah sakit, proses pendataan nama petugas ambulan, proses pendataan nama pemesan dan proses pemesanan ambulan. Berdasarkan analisa kebutuhan yang didapat maka penulis merancang interface yang cocok untuk permasalahan tersebut.Aplikasi ini dirancang menggunakan PHP dan MySQL sebagai penyimpanan data. Pada tahap ini dilakukan observasi ke lokasi penelitian.

Berikut adalah "Analisa Kebutuhan" dari "Aplikasi Pemesanan Ambulan Berbasis Web".

\section{Pelanggan}

1. Pelanggan dapat Login

2. Pelanggan dapat mendaftar jika belum memiliki akun

3. Pelanggan dapat melihat informasi rumah sakit dan jumlah ambulan yang tersedia.

4. Pelanggan dapat melakukan transaksi pemesanan ambulan. 
5. Pelanggan dapat melakukan input data pasien.

6. Pelanggan dapat melakukan pembayaran.

7. Pelanggan dapat melihat riwayat pemesanan ambulan.

8. Pelanggan mendapatkan kamar perawatan

9. Pelanggan dapat melakukan input kritik dan saran.

10. Pelanggan dapat melihat data careers.

\section{Developer}

1. Developer Login terlebih dahulu

2. Developer mengelola data mitra rumah sakit.

3. Developer mengelola data admin mitra rumah sakit.

4. Developer mengelola data careers.

5. Admin dapat melihat laporan admin mitra rumah sakit.

\section{Admin Rumah Sakit}

1. Admin rumah sakit Login terlebih dahulu

2. Admin rumah sakit mengelola data ambulan

3. Admin rumah sakit mengelola data petugas ambulan.

4. Admin rumah sakit mengelola data pelanggan.

5. Admin rumah sakit dapat melakukan konfirmasi pembayaran.

6. Admin rumah sakit mengelola data pasien

7. Admin rumah sakit mengelola data pemesanan.

8. Admin rumah sakit dapat melihat laporan data pemesanan

9. Admin rumah sakit mengelola data kritik dan saran

10. Admin rumah sakit mengelola data pelatihan

\section{Petugas Ambulan}

1. Petugas ambulan Login terlebih dahulu

2. Petugas ambulan dapat melakukan input data ambulan.

3. Petugas ambulan dapat melakukan pendaftaran pelatihan.

\section{Data}

1. Data rumah sakit

2. Data pengguna

3. Data kritik dan saran

4. Data careers

5. Data pelatihan

6. Data pasien

7. Data pemesanan

8. Data pembayaran

\section{Perancangan Sistem (Desain)}

Tahapan berikutnya adalah pembuatan tampilan desain user interface dari sebuah sistem. Pada tahapan desain ini menggunakan software Visual Studio Code untuk membuat tampilan user interface nya. [6]. Dalam perancangan database penulis menggunakan ERD, perancangan sistem menggunakan UML, sedangkan program editor yang digunakan untuk membangun sistem penulis menggunakan Visual Studio Code dengan bahasa pemograman PHP[7].

\section{Pengkodean (Coding)}

Tahapan pengkodean ini merupakan tahapan yang berkaitan dengan tahapan desain. Untuk perancangan web yang dibuat penulis ini menggunakan script PHP maupun HTML, untuk databasenya menggunakan MySQL[8].

\section{Pengujian ( Testing )}

Pengujian pada pembuatan Aplikasi Pemesanan Ambulan Berbasis Web ini menggunakan metode black box testing[9].

\section{Pendukung (support) atau Pemeliharaan (maintenance)}

Mengulangi proses pengembangan mulai dari analisis spesifikasi untuk perubahan perangkat lunak yang sudah ada, tapi tidak untuk membuat perangkat lunak baru.

\section{Hasil dan Pembahasan}

Sistem berjalan saat ini melakukan pemesanan Ambulan melalui telephone, Sistem pemesanan ini berguna bagi pemesan untuk melihat detail rumah sakit dan memesan ambulan menggunakan Sistem Informasi Pemesanan Ambulan. Semoga dengan adanya sistem pemesanan ambulan ini dapat membantu pemesan untuk melihat rumah sakit terdekat dan memesan ambulan.[10] Dalam pembuatan aplikasi ini diawali dengan proses observasi untuk mengidentifikasi dan menganalisa kebutuhan.

a. Use Case Diagram

Use Case Diagram yang diusulkan untuk membangun sistem ini yaitu sebagai berikut :

Pada gambar 1 terdapat 4 actor yaitu developer, admin rumah sakit, petugas ambulan dan pelanggan. Developer dapat Login, mengelola data mitra rumah sakit, mengelola data amin mitra rumah sakit, mengelola data careers, dan menampilkan laporan mitra rumah sakit. Admin rumah sakit dapat login, mengelola data ambulan, mengelola data petugas ambulan, mengelola data pelanggan, melakukan konfirmasi pembayaran, mengelola data pasien, mengelola data pemesanan, menampilan laporan data pemesanan, melakukan input data careers, mengelola data pelatihan. Petugas ambulan dapat login, melakukan input data ambulan, melakukan pendaftaran pelatihan.Pelanggan dapat melihat informasi rumah sakit dengan jumlah ambulan, melakukan register, login, melakukan pemesanan ambulan, melakukan input data pasien, melakukan pembayaran, menampilkan Riwayat pemesanan, melakukan input kritik dan saran, dan menampilkan data carerrs.

\section{b. Activity Diagram}

Activity Diagram ini menekankan pada proses pemesanan ambulan yang dilakukan oleh pelanggan dan hubungan antara admin rumah sakit dengan pelanggan.[11] 
Pada gambar 2 activity diagram ini lebih memfokuskan pada pemesanan ambulan yang dilakukan oleh user dan hubungan pemesanan yang dilakukan antara user dan admin.

\section{c. Class Diagram}

Pada Gambar 3 menunjukan class diagram pada sistem yang dirancang.

\section{Hasil}

Hasil dari penelitian ini adalah sebuah website pemesanan ambulan. Maka dapat disimpulkan sistem berjalan saat ini melakukan pemesanan Ambulan melalui telephone, sistem pemesanan ini berguna bagi pemesan untuk melihat detail rumah sakit dan memesan ambulan menggunakan Sistem Informasi Pemesanan Ambulan. Semoga dengan adanya sistem pemesanan ambulan ini dapat membantu pemesan untuk melihat rumah sakit terdekat dan memesan ambulan.[12]

Analisis sistem yang sedang berjalan ini diperlukan juga sebagai dasar untuk merancang sebuah sistem informasi yang baru, diperlukan adanya suatu gambaran yang memuat informasi yang terhubung dengan sistem yang sedang berjalan. Dengan tujuan mempermudah dalam merancang dan menganalisa sistem yang akan dibuat.[13]

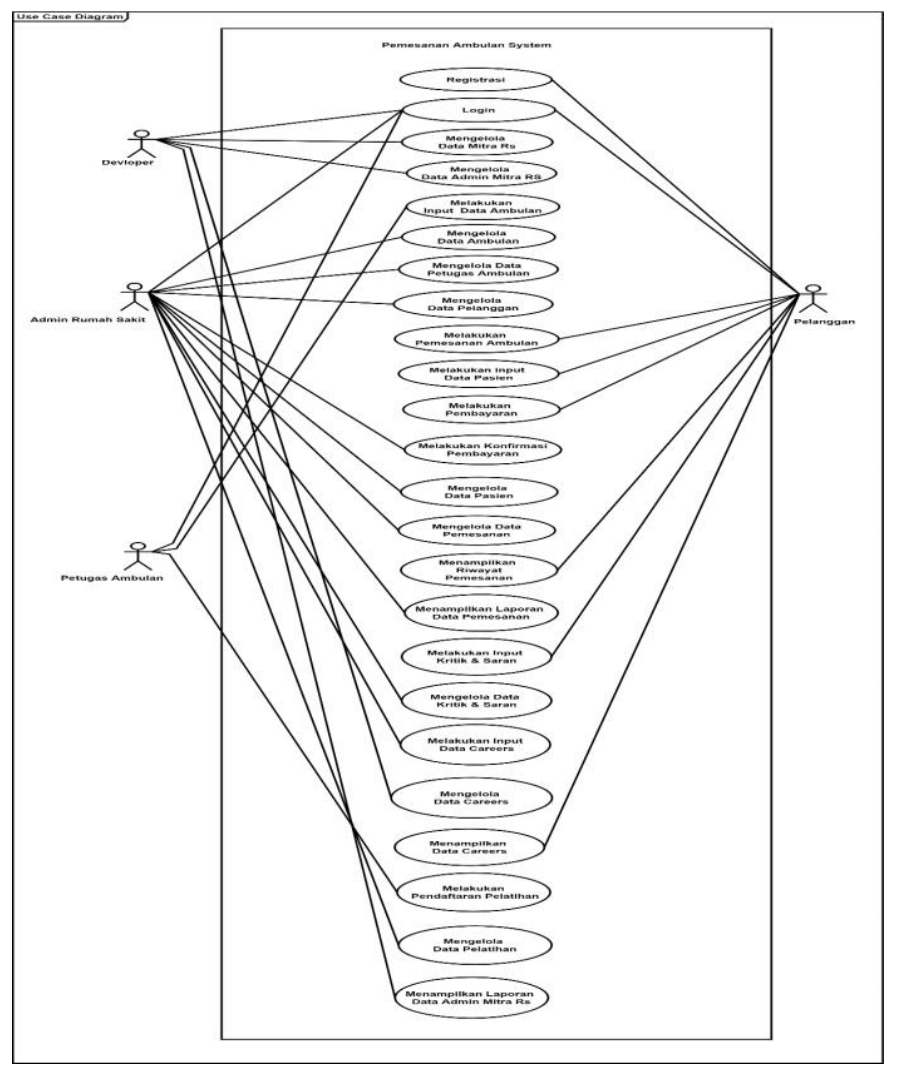

Gambar 1. Use Case Diagram 


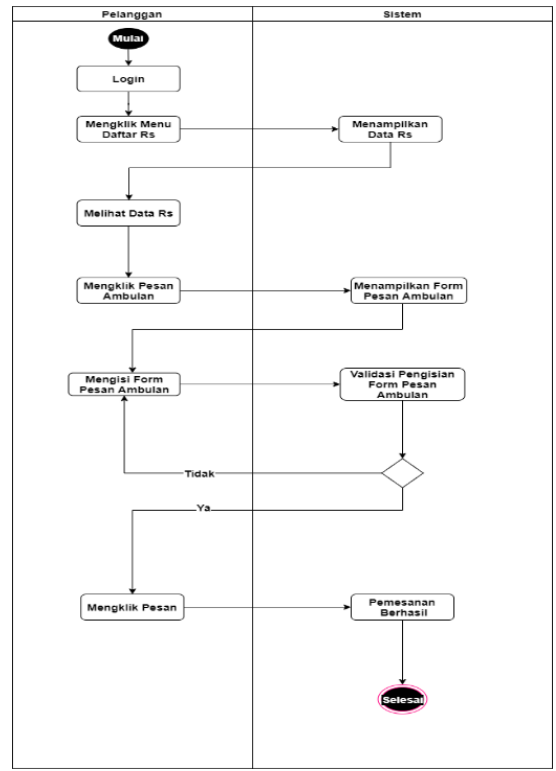

Gambar 2. Activity Diagram

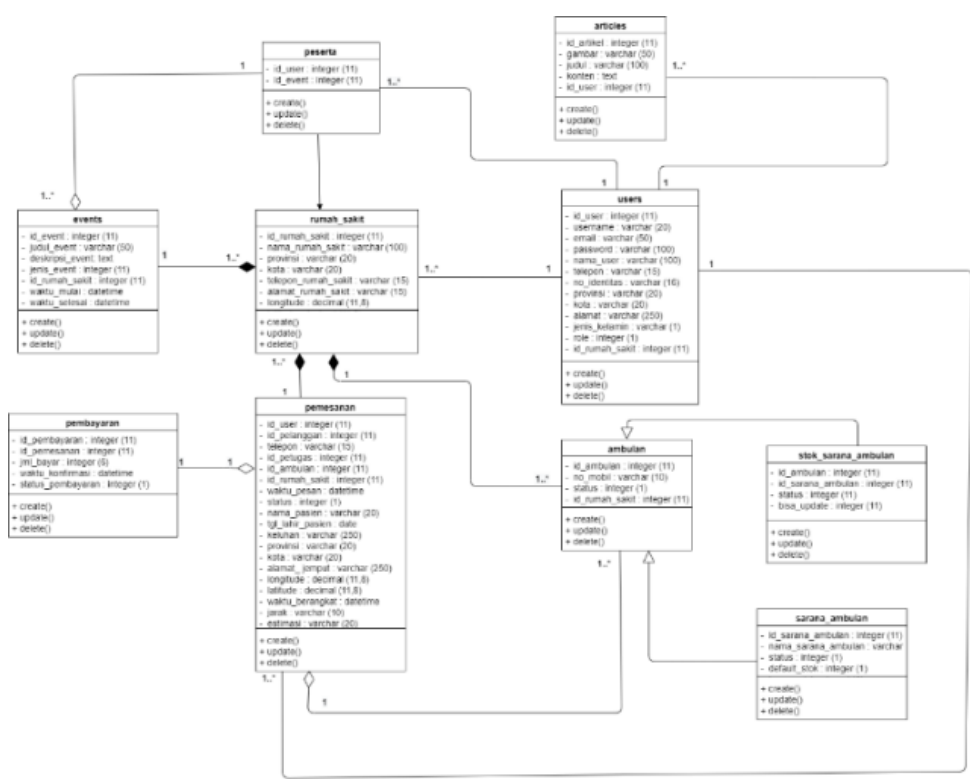

Gambar 3 Class Diagram

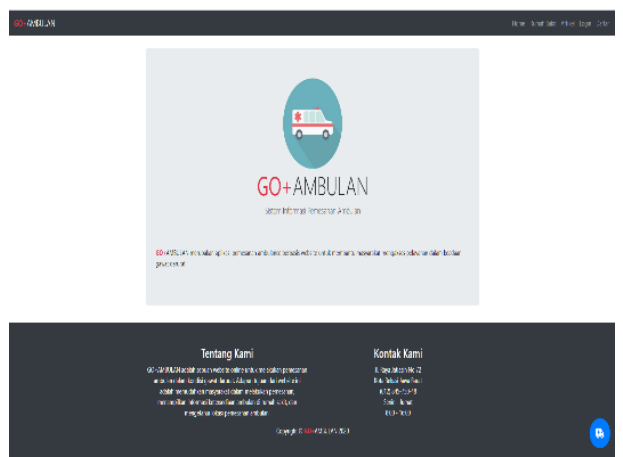

Gambar 4 Tampilan Beranda 
Gambar 4 adalah tampilan Beranda, terdapat beberapa informasi rumah sakit dan pelanggan dapat meng-akses halaman-halaman yang inginkan.

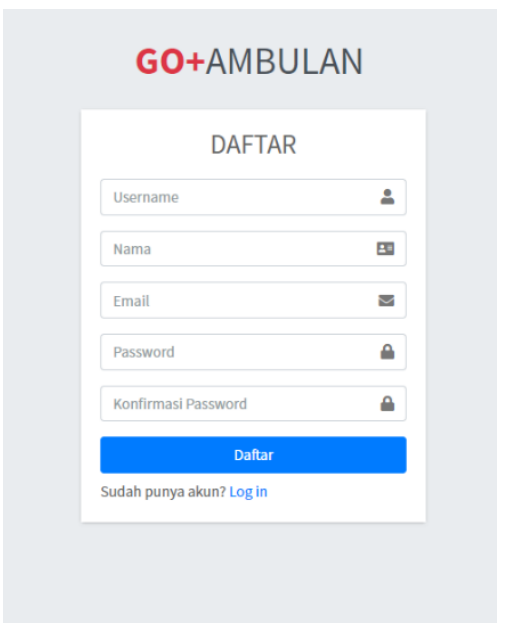

Gambar 5 Tampilan Form Daftar

Pada gambar 5 adalah halaman Form pendaftaran user yang berisi formulir untuk di isi calon user dengan data diri yang sesuai dan dapat di pertanggung jawabkan.

\section{Login user}

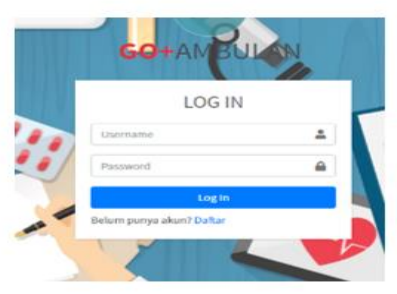

Gambar 6 Tampilan Form Login User

Pada gambar 6 adalah halaman Antarmuka Login User yang diharuskan memasukan username dan password yang sudah terdaftar agar dapat melakukan pemesanan ambulan.

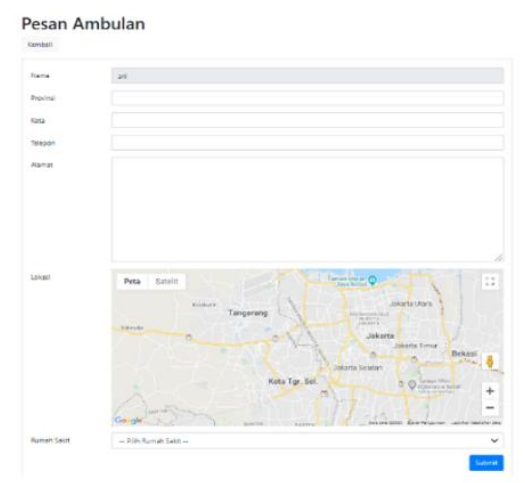

Gambar 7 Tampilan Form Pemesanan
Pada gambar 7 adalah form pemesanan yang berisi data yang harus dilengkapi pelanggan untuk melakukan pemesanan ambulan.

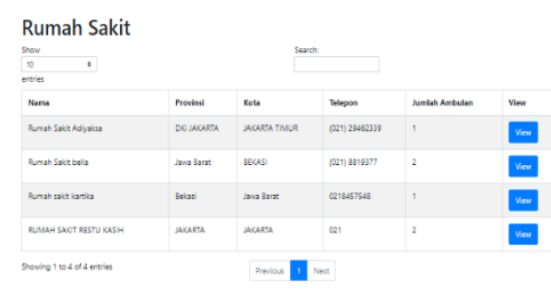

Gambar 8 Tampilan Rumah Sakit

Pada gambar 8 adalah halaman rumah sakit yang berisi informasi jumlah ambulan tersedia di sistem.
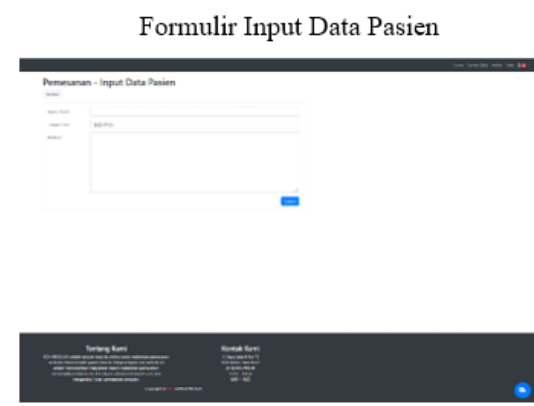

Gambar 9 Tampilan Input Data Pasien

Pada gambar 9 adalah halaman input data pasien, dimana user diharuskan mengisi formulir untuk mendapatkan kamar.

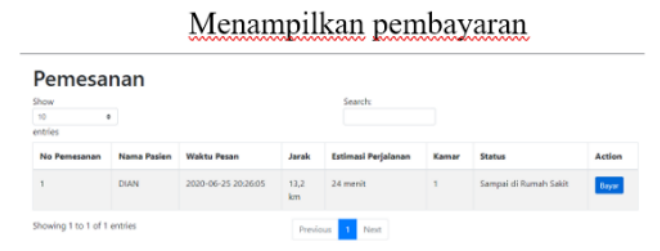

Gambar 10 Tampilan Pembayaran

Pada gambar 10 adalah halaman Antarmuka Pembayaran,pada halaman ini user menampilkan pembayaran setelah ambulan dan pemesan tiba di rumah sakit tujuan.

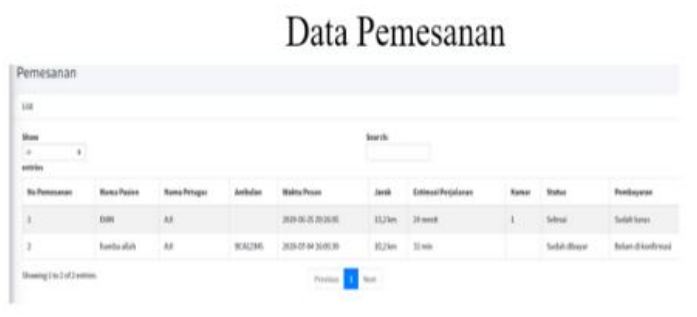


Gambar 11 Tampilan Data Pemesanan Ambulan Pada gambar 11 adalah halaman Data Pemesanan,pada halaman ini menunjukan beberapa pesanan ambulan yang sudah di bayarkan maupun yang belum dibayar,pada halaman ini user dapat mencetak invoice yang sudah dibayarkan.

\section{Data pembayaran}

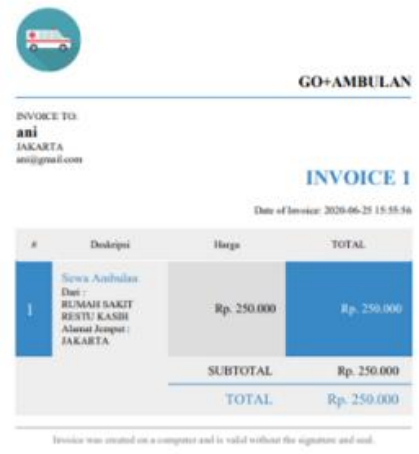

Gambar 12 Tampilan Invoice

Pada gambar 12 adalah invoice yang didapat user setelah melakukan pembayaran sehingga user mendapatkan kamar perawatan di rumah sakit.

\section{Kesimpulan}

Dari pokok pembahasan pada bab sebelumnya, dapat disimpulkan bahwa aplikasi dapat membantu dalam melakukan pemesanan ambulan. Dengan adanya aplikasi ini, user dapat mendapatkan informasi rumah sakit dengan jumlah ambulan yang tersedia. User melakukan pemesanan dengan melakukan registrasi dengan akun email. Hal ini bertujuan untuk mengurangi informasi yang kurang jelas dari ketersediaan ambulan di rumah sakit. Pada proses pembayaran dilakukan dengan media transfer antar bank, dan mengupload bukti pembayaran. Setelah pembayaran dikonfirmasi user akan mendapatkan invoice.

Aplikasi Pemesanan Ambulan Berbasis Web ini, diharapakan dapat mempermudah pemesan untuk melakukan pemesanan ambulan melalui online, menampilkan informasi ketersediaan ambulan di rumah sakit, mengetahui lokasi pemesanan ambulan, mengurangi antrian pembayaran.[14]

\section{Ucapan Terimakasih}

Syukur Alhamdulillah senantiasa di panjatkan kehadirat Allah SWT yang memiliki keistimewaan dan pemberian segala kenikmatan besar. Pada kesempatan kali ini penulis menyampaikan rasa terima kasih yang sebesarbesarnya kepada:

1. Ibu Sri Dianing Asri, St, M.Kom selaku sekprodi Teknik Informatika Fakultas Ilmu Komputer

2. Bapak Fajar Masya, Ir. MMSI selaku dosen pembimbing akademik.

3. Ibu Wuwuh Bekti Hartiningsih, ST, MMSI selaku dosen pembimbing
4. Kedua orang tua yang telah memfasilitasi, memberikan dukungan dan doa dalam pembuatan jurnal ini.

\section{Daftar Pustaka}

[1] Kementerian Kesehatan, Undang Undang Republik Indonesia Nomer 36 Tahun 2009. Jakarta: Kementerian Kesehatan Republik Indonesia, 2009.

[2] Presiden Republik Indonesia, Undang Undang Republik Indonesia Nomer 44 Tahun 2009. Jakarta: Kementerian Kesehatan Republik Indonesia, 2009.

[3] Depkes RI and D. RI, Peraturan Menteri Kesehatan Republik Indonesia Nomor 71 Tabun 2013 Tentang Pelayanan Kesebatan Pada Jaminan Kesebatan Nasional. Jakarta: Kementerian Kesehatan Republik Indonesia, 2013.

[4] S. Salwa Husna, M. Fadli, and D. Hajar, "Rancang Bangun Sistem Pemesanan Tiket Bus Berbasis Mobile pada Perusahaan Otobus di Dumai," J. RESTI (Rekayasa Sist. dan Teknol. Informasi), vol. 2, no. 3, pp. 611-620, 2018, doi: https://doi.org/10.29207/resti.v2i3.507.

[5] Achmad Solichin, Pemrograman Web dengan PHP dan MySQL. Jakarta: Budi Luhur.

[6] M. K. Heru Sulistiono, S.Kom., Coding Mudah dengan CodeIgniter, JQuery, Bootstrap, dan Datatable. Jakarta: Elex Media Komputindo, 2018.

[7] Supono dan Vidiandry Putratama, Pemrograman Web dengan Menggunakan PHP dan Framework Codeigniter. Jakarta: Deepublish, 2018.

[8] Jubilee Enterprise, MySQL untuk Pemula. Jakarta: Elex Media Komputindo, 2014.

[9] Fatmawati, "Perancangan Sistem Informasi Pemesanan Katering Berbasis Web Pada Rumah Makan Tosuka Tangerang," Jurnalteknik Komput. Amik Bsikomputer Amik Bsi, vol. II, no. 2, pp. 24422436, 2016.

[10] M. R. Andini, S. P. Arso, and W. Kusumastuti, "Analisis Pelaksanaan Program Ambulan Siaga Kota Semarang Tahun 2019," J. Kesehat. Masy., vol. 8, pp. 15-21, 2020.

[11] F. Rahman and Santoso, "Aplikasi pemesanan undangan online," J. Sains dan Inform., vol. 1, no. 2, pp. 78-87, 2015, [Online]. Available: https://jsi.politala.ac.id/index.php/JSI/article/vie w/30/29.

[12] A. Acmad, K. Alkakim, F. Pradana, and B. Priyambadha, "Pembangunan Sistem Pemesanan Koki dan Makanan Berbasis Web," J. Pengemb. Teknol. Inf. dan Ilmu Komput., vol. 2, no. 9, pp. 25322537, 2018.

[13] M. Chairudin, K. Setyowati, D. G. Suharto, M. A. Publik, F. Ilmu, and I. Politik, "Inovasi Layanan KesehatanOn-Demand Berbasis Aplikasi Telepon Genggam Untuk Meningkatkan Kualitas Pelayanan Publik," pp. 131-144.

[14] N. Purnautari Handayani and H. Noprisson, "Analisa dan Perancangan Aplikasi Gedtix untuk Pemesanan Gedung Multifungsi di Tigaraksa, Tangerang, Banten," JUSIBI - Jurnal Sist. Inf. dan E- 
Bisnis), vol. xx, no. x, pp. 18-25, 2018, [Online].

Available:

https://jurnal.ikhafi.or.id/index.php/jusibi/18. 